\title{
Human Resource Outsourcing: Issues and Challenges
}

\author{
Amitabh Deo Kodwani
}

\begin{abstract}
Business Process Outsourcing has become new mantra in the corporate business world. Modern as well as traditional organizations are now trimming down their employees from their payroll, and thus Human Resource Outsourcing (HRO) is slowly becoming the new buzzword. In order to utilize the true worth of the employees to its fullest, one must outsource the non-core activities of the organization. The awareness of this has already been realised by the organizations.

Outsourcing has no longer the privilege of only huge multinational organizations. Even the public sector and government undertakings as well medium size or start-up companies are also in the race of outsourcing their many $H R$ related activities.

This paper examines the motives that are encouraging organizations to go for outsourcing $H R$, drawing the essence from extensive exploratory study of secondary literature. This paper presents an architectural framework to understand issues and challenges of HR HRO and to suggest what organizations should do to taste success from HRO.
\end{abstract}

Key words : human resources, outsourcing

\section{Introduction}

The productive capacity of all business depends on three factors: the capital resource, the physical resource and the human resource" -(Peter.F.Ducker)

This statement holds a lot of significance because of the fact that of all the three resources, only the human resources possess the productive capacity for which the upper limits are not defined. So in order to utilize the true worth of the employees to its fullest, one need to outsource the non-core activities of the organization.

Outsourcing can be defined as the situation where an external vendor or service provider provides, on a recurring basis, services that would normally be performed in-house by the organization. In other words it can said that, outsourcing is a process where in organizations concentrate on those aspects of their business processes, which gives them a competitive advantage (called as corebusiness) and contract out or shell out the noncore aspects of their business processes. With the increasing global competition, organizations are looking outsourcing as a means of gaining a comparative advantage over other competitors. Outsourcing is thought to benefit a business by allowing an organization to focus on its "core competencies" or "core processes." In this way, an organization can divert its energy away from peripheral or non-core activities of the business which lies outside of its "true" area of expertise, and instead of that concenterating more energy and focus on what it can does well in order to differentiate itself from other competitors. By outsourcing their noncore activities, organizations would be able to reduce their operating costs too. This is possible by reaping the benefits of a supplier's lower cost structure, which could result from economies of scale or other advantages associated with specialisation available with the outsourcing service provider. One very fine example of this is the BP-Exult deal where Exult handled the administrative elements of compensation, benefits, payroll, organizational development, performance management, employee development, training, recruitment and relocation with 
its web based software and left British Petroleum responsible for HR policy, strategy, professional resources and labor relations. It was observed through literature survey that around 85 per cent of companies have realized that outsourcing critical support services can enhance their competitive edge, without the need to invest in infrastructure.

Some of the companies are outsourcing entire activities where as some of them are outsourcing partially. If we look at the history of HR outsourcing (HRO) industry, it can be traced back to more than five decades, when ADP (Automatic Data Processing) set up its payroll processing services in the US. Today, the company has annual revenues of $\$ 7$ billion and 40,000 associates.(www.citehr.com/information-about-hrbpo-vt7351.html)

Survey conducted by The Conference Board reported that more than three-quarters of companies are either outsourcing their major Human Resource functions or are planning to do so in the near future. Also two-third of the US companies accepted that they fully or partially outsource five or more HR functions.( www.conference-board.org). It is believed that with in five to six years, HR BPO (HRO) companies will employ half of all HR professionals.

Human Resource Outsourcing market is growing vary rapidly. Though for the last three years HRO market remained flat, but in the coming days it will regain momentum and is expected to grow very fast as compared to other functional outsourcing businesses. The global HR outsourcing industry is estimated to reach $\$ 31$ billion in 2007 and $\$ 50$ billion by 2010, representing a compound annual growth rate (CAGR) of 12\% during the 2007-2010 period. [Hewitt Associates, LLC SWOT Analysis, Jun2007, p1, 8p; (AN 25629859)]

India too is witnessing the growth of HRO. The good news for India is that nearly $50 \%$ of HRO business has an offshore component, so a lot of it is actual coming to India. The latent size of HR outsourcing in India is about $\$ 2$ billion with a current market of more than $\$ 27$ million and it is growing at a rate of about 50 per cent (www.Hewitt .com). The first HR BPO in India was started by Secova eServices in Chennai on December 2003, having 50 - seater facility.

Experts believe that in present times HRO is undergoing a transition phase. It is moving out from the realm of bigger companies to small and mid-sized organizations. There has also been a transition in its user acceptance, where it is moving from a corporate domain to PSUs' and the Government sector. All this reflects on the growth of this sector. (http:// www.expressitpeople.com/20030428/cover.shtml).

Another major issue in HRO process is to decide which HR function need to be offloaded and also which firm to outsource. This is one of the biggest challenges, because it may adversely affect company's performance if selected wrongly. Before going for offloading any in-house HR related activity to external agency; one need to be sure about the pros and cons of outsourcing it. Though ther are several benefits of outsourcing HR related activities, there are some shortcomings too.

In a survey of 129 large companies representing nearly 2 million employees it was observed that organizations are satisfied with their HR outsourcing decisions and plan to outsource more HR services by 2008.(findarticles.com/p/articles/mi_m3495/is_6_50/ ai_n13826255). In another survey slightly more than 50 percent of survey respondents reported that they had fully achieved their outsourcing objectives, 42 percent had partially achieved them, and less than 1 percent of outsourced human capital functions had been 
brought back in-house.( http://www.gao.gov/htext/d04679.html)

This paper highlights the various issues and challenges of HRO including the pros and cons of it and recommending what organizations need to take precautions while going of HRO.

\section{Functions of HR outsourcing}

HR outsourcing generally happens in the areas like payroll, employee benefits administration, network, fixed assets administration, receivable and logistics management, hardware maintenance, telemarketing, call centers and database management. In India, the common processes which are outsourced are generally related to training and development, payroll processing, surveys, benchmark studies and statutory compliance.

HR outsourcing continues to grow in the future. More and more HR functions will be outsourced. As per the survey conducted in 2005 by Hewitt Associates, a global human resource services firm on 129 large companies found that $94 \%$ respondents outsource at least one HR function. Further their study highlights that the most commonly almost fully outsourced HR functions are:

\section{Exhibit 1: Functions of HR outsourcing}

\begin{tabular}{|c|l|c|}
\hline & \multicolumn{1}{|c|}{ HR Functions } & \% of Respondents \\
\hline 1. & Outplacement Services & $91 \%$ \\
\hline 2. & Employee Assistance Programs & $89 \%$ \\
\hline 3. & Defined Contributions 401(K) & $84 \%$ \\
\hline 4. & COBRA administration & $77 \%$ \\
\hline 5. & Defined (Pension) & $68 \%$ \\
\hline 6. & Health benefits & $69 \%$ \\
\hline
\end{tabular}

Source www.hewitt.com (Suzanne Zagate \& Jennifer, 2005)

By 2008, companies plan to expand outsourcing into the following areas, listed in order: leave management, learning and development, payroll, recruiting, health and welfare, and global mobility. (findarticles.com/p/articles/mi_m3495/is_6_50/ai_n13826255)

\section{HR outsourcing Suppliers:}

There are three types of HRO suppliers :( According to Phil Fersht, Senior Analyst, Business Process Outsourcing for the Yankee Group)

- Specialists in discrete sub processes of HR like payroll, benefits, hiring and recruiting, and training and education. For exampl; Hewitt Associates and Automatic Data Processing (ADP)

- One-stop-shops that aggregate multiple HR functions into one HRO offering. For example; Exult and Fidelity Employer Services

- Super-suppliers with worldwide processing facilities offering full service at lower cost. They take advantage of economies of scale. For example IBM Business Consulting Services, and Accenture. (http://www.outsourcing-offshore.com/go.html)

Where Hewitt and ADP continue to serve the mid-market buyers with 500 to 2000 employees, one-stop-shop and super-suppliers will focus on buyers with 10,000 or more employees. (http://www.outsourcing-journal.com/feb2004adpstudy.html?email004956) 


\section{Drivers of Human Resource Outsourcing}

Much of the literature available on outsourcing in general has examined the rationale behind such decisions. The key considerations behind HRO being the need for increased focus on core business, cost reductions; greater business flexibility and need for specialized expertise (Jennings 1996, Bettis et.al. 1992, Quinn et.al. 1990).

HR outsourcing is sometimes driven by the evolution of the HR function within the organizations (Greer et al., 1999). The literature suggests extensive use of outsourcing because of the relatively underdeveloped HR function in their organization or where it is being restructured. But outsourcing in such organizations is confined to administering compensation and benefits, record keeping, and applicant screening. (NICOM, 2005) Further literature review highlights that there are three main motivators for HR outsourcing, they are reduce overall HR service delivery costs $(37 \%$, free time for strategic HR $(23 \%)$, and improve service quality (14\%). Other reasons are highlighted in exhibit 7 given below.

\section{Exhibit: 7}

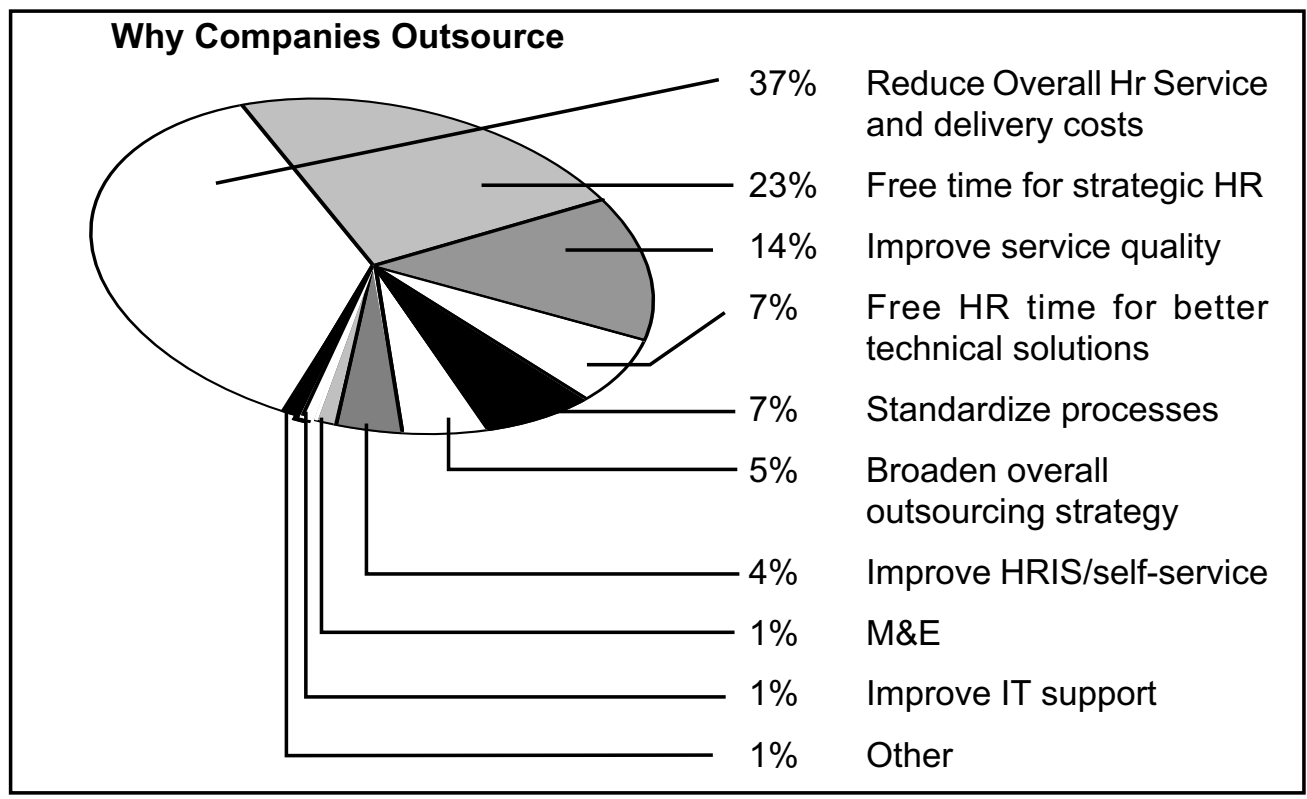

Source: HR Outsourcing: New Realities, New Expectations (2005 HR Outsourcing Effectiveness Survey Report) www.towersperrin.com

Cost reduction has been the predominant motive for outsourcing (Hoek, 1999). As per one of the survey conducted in 2005 , around $37 \%$ of the respondents accepted that cost reduction is one of the prime factors as compared to $32 \%$ in 2004 (www.towersperrin.com). Outsourcing decisions commonly target a minimum of 15 per cent cost saving and sometimes in the range of 20-25 per cent (Jennings, 2002; Bounfour, 1999).

Third important reason as cited in the survey (exhibit 7) is improving service quality. Not only external customers need to be satisfied for successful business operations but internal customers too play a vital role and thus they also need to taken care of. By improving service quality, HR professionals can help organization to satisfy their employees as 
well their customers. There are other reasons too as cited by the survey. Though none of the rest of the issues crossed $10 \%$, but will definitely be the important issues in the future. These issues are; free HR time for better technical solutions (7\%), standardize processes (7\%), improves HRIS (4\%), etc.

\section{Benefits and Satisfaction With HRO:}

The biggest contribution is in converting fixed cost to variable cost, and reducing additional processing cost, ongoing expenditures and capital outlay. Infact the savings in the capital outlay has been of main concern in the government organizations that have been operating with decades-old legacy mainframe systems and now want to upgrade their services that can provide a better work environment for employees, especially the younger, technically-savvy employees who are working for the government and are demanding Webenabled HR services. (http://www.outsourcing-hr.com/private.html)

Credit Suisse First Boston estimates that it has saved \$115 millon since 1994 by outsourcing most of its transactional human resource functions. Don Packham, vice President of Human Resources for BP Amco's US operations, reports savings of \$ 50 million in the first two and half years of BP's outsourcing contract. Similarly Cydney Kilduff, Director of Recruiting and staffing at Kellogg, mentioned that the outsourcing had reduced the time it took to fill vacancies at Kellogg from 67 days to 39 days, and the cost per hire was reduced from $\$ 7905$ to $\$ 3784$. (www.aon.com)

Let us look at the satisfaction level of those companies who have outsourced their HR functions, as mentioned in various studies:

Exhibit 8: Benefits of HR outsourcing

\begin{tabular}{|c|l|c|}
\hline \multicolumn{1}{|c|}{ Satisfaction level } & \% of respondents \\
\hline 1. & Fully Satisfied & $89 \%$ \\
\hline 2. & Achieved hope for benefits & $85 \%$ \\
\hline 3. & Unexpected benefits & $20 \%$ \\
\hline 4. & Achieving Cost Savings & $45 \%$ \\
\hline 5. & Outsourcing transaction smoothly & $81 \%$ \\
\hline 6. & Outsourcing function brought back in-house & $23 \%$ \\
\hline 7. & Continue with the same vendor & $70 \%$ \\
\hline
\end{tabular}

Source (www.aon.com, www.towersperrin.com and www.hewitt.com)

If we look at the above mentioned exhibit, it clearly indicates the benefits of HR outsourcing. The overall satisfaction level has gone up from 51\% in 2002 to $89 \%$ in 2005 . Another issue is of outsourcing function brought back in-house, which has been mentioned by $23 \%$ respondents. Actually out of this $23 \%, 68 \%$ of the companies have brought back their outsourced function because of poor services provided by the vendor, whereas only 32 $\%$ of the companies said that they brought back because they did not achieved anticipated cost savings. (www.aon.com, www.towersperrin.com and www.hewitt.com)

\section{Drawbacks or problems of HRO:}

One of the problems with HRO is difficulty in accepting the change by the employees of the organization. There is also anxiety about losing control over the process and lay 
off. Such employees reactions generally create difficulty in outsourcing. This resistance will be higher when more scope is added later. Effective communications and change management programs (OD initiatives) are especially crucial at this stage when the new scope involves implementing a self-service platform. Actually such systems are not intuitively obvious. Employees need to be helped to adopt to this the new system.

Also there are various risks associated with HRO. One of such risk is the business risk which may arise due to cheap outsourcing contracts. There is also spillover risk, i.e. exposing of confidential matters to competitors. Political risks is another issue in outsourcing. One such example of this is the controversial issue in the US during the time of elections when opposition blamed outsourcing for unemployment and wanted it to be banned. Another problem in HRO is that sometiimes it brings threat to the organization culture and it gets totally out of control if gone into the hands of unsympathetic outsourcers. Also vendor organization should be well aware with the laws and should act in compliance with laws of his and client's country otherwise legal issues may crop up and may adversly affect organization.

One more problem that arises is the loss of personal touch with the employees. Because an in-house HR person interacts daily with your employees, they will likely have more of an interest in your employees. This is the reason why Morgan and Stanley decided to provide retirement planning services in-house. The loss of talent generated internally, potential redundancies, fear of service provider ceasing the trade, loss of concentration on customer and more focus on the product are other drawbacks or challenges of HRO.

Also when an organization is using a PEO, giving up the right to hire and fire thier employees, may not be desirable for their particular business. Mostly PEOs insist that they should have the final right to hire, fire, and to discipline employees. This may not be healthy for an organization in the long run. And if an organization decide to use an E-service, the same issues would remain with any ASP. When everything is stored and handled online, there might be concerns about the security as well as the potential crashes, both of which can be detrimental to any business organization. Common complaints about HR outsourcing range from payroll mix-ups to payroll not being deposited on time to denied medical claims. (www.entrepreneur.com/humanresources/employmentlaw/article58222.html)

Vendor selection is another major issue in outsourcing HR. If we select the wrong vendor, then we won't be able to enjoy the fruits as expected from HRO. Companies say that one of the important requirements while selecting vendor for outsourcing HR is vendor's demonstrated HR process expertise, which has been responded by $95 \%$ respondents as mentioned in the survey conducted by Hewitt associates in the year 2005. (www.Hewitt .com).

\section{What Companies Should Do To Have Successful HR Outsourcing?}

Drawbacks can be compensated if an organization takes necessary precautions of paying more attention to process redesign and details, and at the same time keeps strategic parts of HR like Human Resource Planning in-house, as it revolves around critical activities and core capabilities and thus provides sustainable lead in the long run. This is the reason why HR activities like payroll processing is generally outsourced since it provides less competitive advantage and is a non-core activity for any organization. Thus there is need to 
create a balance between external service providers and internal operatorsOrganizations need to outsource thier HR activities as per their size. Small and mid sized organizations should outsource HR activities like payroll because they may lack economies of scale to perform that function efficiently. Large companies should outsource HR activities like benefit processing because then broader range of benefits are offered which reduce the economies of scale of handling the activity in-house.

In case of multi-supplier situation, good governance, change management, and effective dispute resolution structure need to be in place. It should be ensured by the organizations that all the parties should work together nicely. However long-term contracts can be avoided as things are changing rapidly.

Since outsourcers are the third party, communication travels three ways rather than two ways involving organization, vendor and employees, giving room for mistakes. In such case communication plays a very vital role. Sears, Roebuck and Co., retail giant was aware of this issue. Hence it selected Hewitt Associates as their HR service provider to take over the work and both companies ranked communications and commitment to mutual goals as the top two keys to their success. This is also the foundation for their ability to adapt to change quickly and to innovate in order to achieve the desired objectives. (http:// www.outsourcing-hr.com/reaping.html)

\section{Conclusion}

This article tried to highlight the overll concept of HRO and identify the main issues and and challenges relating to outsourcing HR. The reviews of literature, as well as of recent surveys by various organizations, show that HRO market is growing and will grow faster than the current rate. Mike Christie, HR Outsourcing Consultant with Hewitt Associates, says Hewitt posted a 15 percent increase in overall revenues last year. Most of the increased activity was in its core business i.e. benefits, workforce administration, and payroll. (http://www.outsourcing-offshore.com/go.html). HRO is of most interest in those sectors of economy which are experiencing the margin pressure.

Though there are many benefits of HRO, which can not be denied but at the same time we need to address various challenges of HRO. One has to take lot of precaution while planning for ooutsourcing their HR activities. It was also oberved that in the recent times outsourcing has undergone lot of advancement due to increased data security because of new technology and changing perception of what can and cannot be outsourced but security issue still demands attention i.e. how comfortable are buyers with having their proprietary data being transmitted offshore.

Also suppliers need to evolve additional metrics that aren't transactional in nature and that measure more strategic value like workforce productivity, absenteeism rates, and employee turnover.

Offshoring HRO is booming and this is good sign for country like India, but suppliers need to address several issues to maintain this momentum. Offshore employees which are hired to do simple manual process work can't be expected to demonstrate advanced expertise such as understanding different health care plans in different countries or answering policy-based questions.

HRO is also becoming more self-service. Company personnel are forced to perform 
HR activities like withdrawing money from their $401(\mathrm{k})$ plans using self-service over the Web. This requires employees to be more proactive, and suppliers have not yet defined the self-service line beyond which buyers' personnel are hesitant to go. (http://www.outsourcingoffshore.com/go.html).

HR Outsourcing must also be carefully evaluated and weighed against issues such as control, the strategic value of technology to the organization, staffing, responsiveness/ accountability, and, of course, overall costs.

If organizations have a broader perspective and are taking corrective measures before going for HRO then outsourcing will certainly help in coping with the peaks and troughs of the business. Properly applied, including concerns, outsourcing offers many benefits; otherwise, it offers even greater risks.Like most everything in life, HRO has come a long way. But there's still a long way to go.

\section{REFERENCES}

Bettis, R.A., Bradley, S.P., Hamel, G. (1992), "Outsourcing and industrial decline", Academy of Management Executive, 6(1):7-22.

Bounfour, A. (1999), "Is Outsourcing of intangibles a real source of competitive advantage?", International Journal of Applied Quality Management, 2, 127-151.

Greer, C.,Youngblood, S. and Gray, D. (1999), "Human Resources Management Outsourcing: The Make or Buy Decision", Academy of Management Journal .

Hewitt Associates, LLC SWOT Analysis, Jun2007, p1, 8p; (AN 25629859)

Jennings, D. (2002), "Strategic Sourcing : Benefits, Problems and a Contextual Model", Management Decision, 40(1) : 26-34.

Jennings, D.R. (1996), “Outsourcing Opportunities for Financial Services”, Long Range Planning, 29(3):393-404.

Quinn, J.B., Doorley, T.L., Paquette, P.C. (1990), "Technology in services: rethinking strategic focus", Sloan Management Review, Winter: 79-87.

Ramachandran K and Voleti S (January-March 2004), "Business Process Outsourcing (BPO): Emerging scenario and strategic options for IT-enabled services", VIKALPA, 29(1): 49-62

Van Hoek, R.I. (1999), "Postponement and the reconfiguration challenge for food supply chains", Supply Chain Management, 4 (1): 18-34.

- $\quad$ www. Hewitt.com

- $\quad$ www.aon.com

- $\quad$ www.citehr.com/information-about-hrbpo-vt7351.html)

- $\quad$ www.conference-board.org

- $\quad$ www.entrepreneur.com/humanresources/employmentlaw/article58222.html

- $\quad$ www.everestgrp.com/files/howtomakefullservicehrowork.pdf (How to make full service HRO work for you: by By Richard Kabrt and Beth Ellyn Rosenthal)

- $\quad$ www.expressitpeople.com/20030428/cover.shtml

- $\quad$ www.findarticles.com/p/articles/mi_m3495/is_6_50/ai_n13826255

- $\quad$ www.gao.gov/htext/d04679.html

- $\quad$ www.hewitt.com (Suzanne Zagate \& Jennifer, 2005)

- $\quad$ www.hewittasia.com/hewitt/ap/resource/articleindex/articles/print/delivery_dummies.htm

- $\quad$ www.HR logistics.com

- $\quad$ www.hubiz.net/pds

- $\quad$ www.outsourcing-best-practices.com/scope.html (Should You Increase the Scope of Your HR Outsourcing? By Peter Bendor-Samuel, CEO, Everest Group) 
- www.outsourcing-centre.com

- www.outsourcing-hr.com/consolidation.html (The Impact of Consolidation in Human Resources Outsourcing; By John Harney, Business Writer; Publish Date: May 2004)

- $\quad$ www.outsourcing-hr.com/handling.html (Handling an Emergency: Outsourcing Provider Delivers Creative Solutions in Times of Crisis: By Beth Ellyn Rosenthal, Editor; Publish Date: September 2004)

- www.outsourcing-hr.com/private.html (Governments Join Private Sector In HRO Adoption By Beth Ellyn Rosenthal, Editor)

- $\quad$ www.outsourcing-hr.com/reaping.html (Reaping What They Sowed in Outsourcing By Kathleen Goolsby, Senior Writer, July 2004)

- $\quad$ www.outsourcing-journal.com/feb2004-adpstudy.html?email004956 (What Is the Cost of Owning an In-House HR System? By Beth Ellyn Rosenthal, Editor )

- www.outsourcing-offshore.com/go.html (HR Outsourcing: Where It Needs To Go, By John Harney, Business Writer )

- $\quad$ www.rediff.com/money/2004/may/03bpo1.htm (The new mantra is HR outsourcing by Madhuri Sehgal in New Delhi | May 03, 2004 10:09 IST)

- www.regionals4.gartner.com/regionalization/img/gpress/pdf/ gartner_exec_report_sample_SOURCE.pdf

- $\quad$ www.towersperrin.com (2005 HR Outsourcing Effectiveness Survey Report)

- $\quad$ www.xplegal.net/international_outsourcing_ventures.htm

- www.yankeegroup.com 